\title{
Навстречу Западу: азербайджанский опыт работы по ПСОСО
}

\author{
Томас Федисин ${ }^{*}$
}

При ведении внешней политики, направленной на неухудшение отношений ни с одним из своих соседей и на модернизацию своего общества и вооруженных сил, Азербайджан сталкивается с рядом проблем и возможностей. Не выражая до сих пор желания стать членом НАТО, Азербайджан хотел бы воспользоваться всеми ресурсами, которые НАТО предоставляет странам, желающим вступить в Альянс и другим партнерам по инициативе «Партнерство ради Мира». Таким образом, Азербайджан стоит перед дилеммой, куда в итоге направиться, в то же время не заходя слишком далеко.

С другой стороны, это секуляристское мусульманское государство является идеальным кандидатом на модернизацию вооруженных сил, имея возможность поднять их уровень до стандартов НАТО. Расположенный на берегу Каспийского моря, Азербайджан гордится способностью поддерживать дружеские отношения со своими соседями, в то же время проецируя на международной сцене образ региональной силы и боевой готовности. Его столица, Баку, очевидно утопает в нефтяных прибылях, о чем свидетельствуют ухоженные общественные места, величественные образцы современной архитектуры и модные магазины, равные которым можно найти далеко не во всех европейских столицах. Молодежь гуляет по бульварам Баку в одежде в западном стиле и слушает европейскую поп-музыку. Однако, страна хранит национальную культуру и традиции, которые весьма настороженно относятся к западным идеям. Вне больших городов, общество Азербайджана как-то нехотя переходит в двадцать первый век. И Россия на севере, и Иран на юге страны посылают неуловимые сигналы, что европеизация является не только неправильной, но и нереалистической моделью развития. К этим трениям прибавляется и неприятная реальность факта, что Азербайджан продолжает быть втянутым в «замороженный конфликт» с Арменией по поводу статуса Нагорного Карабаха. Разнонаправленное действие этих сил делает определение «стратегического направления» трудным решением. В этой статье обосновывается утверждение, что создание и развитие программы образования в сфере обороны, направленной на оказание помощи азербайджанским вооруженным силам развиваться по западной (НАТО) модели, является серьезным фактором в попытках убедить Азербайджан обратить свой взгляд на Запад.

\footnotetext{
Доктор Томас Федисин является академическим соруководителем со стороны НАТО азербайджанской программы ПСОСО. Он профессор по делам национальной безопасности и директор Группы европейско-российских исследований в Военно-морском колледже в Нью-Порте, Род Айланд, США. Бывший морской офицер, он командовал крейсером и эсминцем, был военно-морским атташе в России. Имеет много публикаций по вопросам НАТО, российского военно-морского флота и военно-морской стратегии.
} 


\section{Ремоделирование образования в сфере обороны}

В 2008 году азербайджанское министерство обороны решило усовершенствовать систему профессионального военного образования с помощью НАТО, после того как стало ясно, что все его соседи на Кавказе пришли к такому же решению. В своем Индивидуальном плане действий по партнерству (ИПДП), Баку заявил свою заинтересованность в оказании помощи нескольким областям образования, включающим квалификацию сержантского состава, специальную подготовку офицеров и существенное реформирование военного образования высших офицеров, проводимое в Военном колледже вооруженных сил (ВКВС) в Баку. Вследствие этого в 2009 году Азербайджаном совместно с НАТО было начато выполнение Программы Совершенствования Образования в Сфере Обороны (ПСОСО).

Первый элемент программы, подготовка сержантского состава, обеспечивался представителями Союзного командования по трансформации (СКТ), Союзным командованием операций (СКО), Литвой и Соединенными Штатами. В результате нескольких визитов рабочей группы был разработан план развития и применения целостного подхода повышения роли и положения азербайджанского корпуса кадровых сержантов. Группа НАТО сфокусировала свои усилия на создание курсов для карьерного развития сержантов и подготовку инструкторов для обучения сержантов.

Специализированная подготовка офицеров, второй элемент программы, начался анализом курсов, предлагаемых в Азербайджанском центре обучения и квалификации представителями НАТО из Чешской Республики, Польши, Румынии и Соединенных Штатов. Это технические и тактические по своему характеру курсы, которые предназначены для профессионального военного развития младших офицеров. Оба упомянутых выше элемента поддерживаются Европейским партнерским центром для тестирования языковой подготовки (ЕПЦТЯП) с целью создания независимого азербайджанского потенциала для языковой подготовки. Используя оценки структур, обеспечивающих языковую подготовку, Бюро НАТО международной языковой координации (БМЯК) оказалось в состоянии предоставить программы подготовки и конкретную помощь, не упуская из виду задачу создать независимый азербайджанский потенциал для проведения языковой подготовки. Дополнительно к этому азербайджанские слушатели регулярно посещают различные курсы в учебных заведениях НАТО по широкому кругу профессиональных и технических вопросов. Их основная цель состоит в обеспечении оперативной совместимости между вооруженными силами Азербайджана и НАТО в областях, связанных с логистикой и операциями по поддержанию мира.

\section{Профессиональное военное образование старших офицеров}

Третьим - и наиболее важным - элементом инициативы ПСОСО является попытка усовершенствовать и модернизировать курсы обучения для высших военных и гражданских должностных лиц в Азербайджане. Известный в Соединенных Штатах как Совместное профессиональное военное образование (СПВО), этот 
проект начался в конце 2009 года проведением консультаций между представителями НАТО и высшим руководством азербайджанского ВКВС (азербайджанского аналога стратегического военного колледжа). Главным желанием Баку было улучшить программу по стратегии и планированию обороны. Последовала воодушевленная реакция НАТО. Альянс придерживался философии последовательного развития оборонной образовательной инфраструктуры Азербайджана, которая позволит ему в итоге эмансипироваться от НАТО. Выполнение этой задачи на бакалаврском уровне, однако, является гораздо более сложной задачей, чем просто «тренировать тренеров», мотто квалификации сержантского состава и младших офицеров, потому что существует качественная разница между образованием и профессиональной квалификацией.

Первый шаг НАТО заключался в том, чтобы нанять постоянную команду из профессионалов, работавших в стратегическом военном колледже, способных анализировать все элементы проблемы и разработать стратегию для подготовки программы конкретно для Азербайджана, которая позволит вести занятия местным преподавателям. Руководство академической группы НАТО сначала осуществлялось Национальным университетом обороны США, а впоследствии - профессором по национальной безопасности из Стратегического военно-морского колледжа США. В группу входили преподаватели из Стратегического военноморского колледжа в Ньюпорте и Стратегического военного колледжа сухопутных войск в Форт Ливенуорте, а так же из Национальных университетов обороны Чешской Республики и Польши. Первой проблемой, в стране на военном положении, было убедить азербайджанских военных, что разработка «оперативно-стратегической» перспективы должна идти рука об руку с разрешением злободневных вопросов оперативно-тактического уровня. Существующие учебные программы в ВКВС (ориентированного на средний уровень СПВО) были сфокусированы на непосредственных тактических вопросах, связанных с нагорно-карабахским конфликтом с Арменией. Большинство слушателей этого двухгодичного курса были майорами, только что вернувшимися с поля боя. Второй проблемой была необходимость переделать программу и стиль преподавания, которые были основаны на советской философии и педагогике. И преподаватели и слушатели знали только один метод обучения, и большинство из них считали его педагогически неэффективным. И последнее, они должны были разработать план, как местный преподавательский состав будет обеспечивать реализацию нового учебного плана и нового стиля преподавания после ухода команды программы НАТО ПСОСО.

Консультации по текущему состоянию учебных программ были очень конструктивными, благодаря энтузиазму руководства и преподавательского состава ВКВС в принятии более «западного» курса учебы. Не удивительно, что большинство военных колледжей НАТО применяют одну и ту же логику стратегии в определении требований к планированию строительства вооруженных сил (стратегия и планирование обороны). Полученная в результате программа требует познаний в сфере международных отношений, политических наук и региональных исследований, подкрепленных пониманием принципов лидерства, менеджмента, психоло- 
гии, экономики и этики. Азербайджанский преподавательский состав включал как военных, так и гражданских преподавателей, причем гражданские профессоры имели достаточно академических полномочий для проведения академической части трансформации. Существенная помощь со стороны их коллег из НАТО стала эффективным катализатором. Она нашла выражение в последовательности визитов команды НАТО, которые были сфокусированы на демонстрацию преподавательских технологий в классе и на углубленное обсуждение с профессорскопреподавательским составом содержания программ.

Еще первые посещения занятий в классе экспертами НАТО показали, что методики преподавания в постсоветских стратегических военных колледжах и в колледжах НАТО совершенно несовместимы. Характерные для Ньюпорта активные семинары в составе небольших групп, с постоянным участием студентов ярко контрастировали с аудиториями, полными слушателей, ожидающих формальную лекцию по теме дня. Группе НАТО было нетрудно убедить руководство и профессорско-преподавательский состав ВКВС в ценности применения метода Сократа (студенты задают вопросы друг другу и в итоге помогают друг другу) в аудиториях колледжа, хотя обе стороны признали существование барьеров обусловленными культурными, общественными и историческими факторами. Поэтому рабочие группы НАТО решили, что каждый визит будет включать не только консультации между преподавателями, но и «лекции» профессоров из стран НАТО, которые постепенно будут переходить в семинарные дискуссии взамен односторонней коммуникации.

\section{Инициатива преподавателей-дублеров}

Визиты в страну-партнер (обычно три раза в году) оказались недостаточными для инициирования всех аспектов трансформирования образования. Разработка программ, основанная единственно на печатных материалах, на записках и на профессиональных дискуссиях, организованных западными экспертами в ходе этих визитов, не давали достаточного импульса, который позволил бы осуществление реформ в короткие сроки. Да к тому же не все материалы были подготовлены для условий Азербайджана, и местным преподавателям приходилось адаптировать их прежде чем можно было бы их использовать на занятиях в ВКВС. Поэтому, с целью оживить программу, в 2009 группа НАТО году предложила «Инициативу преподавателей-дублеров», по идее которой азербайджанские преподаватели должны были проводить несколько недель в западных военных колледжах, практически являясь дублерами своих коллег-преподавателей, работающих там. Они не только должны были получить методом погружения представление о том, как функционируют западные семинары, но так же увидеть, как готовятся преподаватели к занятиям, посещать «мастер-классы» для подготовки последующих сессий и достичь лучшего понимания гибкости западного стиля преподавания. За последние два учебные года двое азербайджанских профессоров побывали «дублерами» в Ньюпорте в течение почти двух недель. Они вернулись в свою страну не только с пачками академических материалов, но и с лучшим пониманием того, как выс- 
шие профессиональные военные в США развивают свое понимание проблем национальной безопасности. Во время их последнего визита они присутствовали на занятиях по лидерству, военной истории, военно-гражданских отношений и этике, дополнительно к основной программе посещения занятий по стратегии и планированию обороны. Фокусом второго визита была их презентация профессиональной лекции по проблемам национальной безопасности Азербайджана перед преподавательским составом Ньюпорта.

Следуя схеме посещений в Соединенные Штаты, преподаватели ВКВС имели подобные, хотя и более короткие, визиты в университеты обороны Польши и Чешской Республики. Их стоит отметить отдельно, поскольку у Азербайджана много сходных особенностей с этими странами, так как все они являются европейскими странами со средними по численности вооруженными силами, которые в прошлом были связаны (или были в составе) Советского союза. Далее, Азербайджан хотел, чтобы его колледж, как и колледжи в Европе, присуждал ученые степени. И Польша, и Чешская Республика применяют европейскую систему, основанную на Болонской модели, и европейские члены рабочей группы НАТО были уверены, что Азербайджан может пойти по тому же пути. Поэтому большая часть «дублирования» в Брно (Чешская республика) и в Варшаве (Польша) было направлено на объяснение азербайджанским преподавателям конструкции Болонской системы, которую можно было бы использовать в Азербайджане. Вследствие чего планы Азербайджана давать магистерские степени в области военных наук двинулись вперед большими шагами и кульминация этого процесса будет достигнута в 2014 году, когда ВКВС присудит первые магистерские степени выпускникам двухгодичного оперативно-тактического курса. Румыния, другой член НАТО, тоже выразила желание работать с Азербайджаном по проблемам профессионального военного образования.

Второй инициативой, предложенной группой НАТО, было проведение в конце учебного года завершающего практического занятия, позволяющего слушателям интегрировать знания, полученные на занятиях, путем разработки стратегии национальной безопасности для Азербайджана, соответствующих оперативных концепций, необходимых боевых способностей и, в итоге, оборонного бюджета. И снова эта работа потребовала немалых усилий со стороны профессорско-преподавательского состава ВКВС, так как слушатели курса для офицеров среднего уровня командования слишком загружены оперативно-тактическими (а не стратегическими) вопросами, и они считают, что определение национальной стратегии находится полностью за пределами их статуса и старшинства. Несмотря на это, преподавательский состав ВКВС вознамеривается ввести такое занятие в программу курса для офицеров среднего уровня.

За три года азербайджанский курс обучения будущих военных лидеров (сегодняшних майоров) претерпел революционные изменения. Усилия международной группы привели к существенной переделке как учебных планов, так и методики обучения для двухгодичного курса СПВО офицеров со званиями среднего уровня. 


\section{Расширение спектра предлагаемых курсов}

Рабочая группа НАТО было приятно удивлена, когда узнала, что майоры не являются единственными слушателями, поступающими в ВКВС. Действительно, существовал так же межведомственный менеджерский курс для высших должностных лиц, куда принимали около двадцати студентов, причем из министерства обороны была меньшая часть. Этот курс был утвержден в 1999 году и занятия проводились только до обеда в течение пяти месяцев, поскольку предполагалось, что слушатели ходят на работу во второй половине дня. Этот курс стал качественно новым вызовом для команды ПСОСО, потому что слушатели уже были опытными практиками в мире оборонного менеджмента и они привыкли к семинарному стилю работы. На начальных этапах подготовки этого курса существенную помощь оказало министерство обороны Турции.

Содействие НАТО в совершенствовании курса было сфокусировано на применении подхода «участие всего управления» к проблемам безопасности, с которыми сталкивается Азербайджан. Руководство страны должно было учитывать не только «замороженный конфликт» в Нагорном Карабахе, но также и проблемы, связанные с энергетической безопасностью, загрязнением окружающей среды, альянсами и местными террористическими движениями. Хотя немногие из студентов этого курса получили до этого образование в западном стиле, они исключительно хорошо восприняли стиль семинарного участия, который предлагала рабочая группа НАТО. Усилия НАТО были сосредоточены на технологиях межведомственного планирования, и в курс было добавлено заключительное практическое занятие, подобное тому, что было включено в курс СПВО. По счастливой случайности, некоторые из слушателей этого курса были знакомы с работой планировщиков из Военно-морского стратегического колледжа, которые помогали им разработать аварийный план защиты национальной нефтяной инфраструктуры в Каспийском море в 2008-2009 годах.

Одна последняя (и может быть, наибольшая) возможность представилась команде НАТО, когда начальник ВКВС объявил в начале 2012 года о решении создать десятимесячный курс высших офицеров для тех полковников, которые были выбраны для производства в звание генерала и для других перспективных старших офицеров. В ноябре 2012 года Азербайджан решил, что пятимесячный курс будет включен в этот новый курс как модуль по национальной безопасности и будет добавлен пятимесячный сегмент по «оперативно-стратегическим» вопросам. Предвидится начать ведение этого курса с осени 2013 года в составе от пятнадцати до двадцати слушателей. Гражданские слушатели будут участвовать только в сегменте по национальной безопасности (первые пять месяцев курса). Цель состоит в том, чтобы создать курс стратегического уровня, позволяющий выпускникам быть как боевыми командирами на стратегическим уровне, так и профессионалами стратегии и планирования обороны, работающими в администрации министерства обороны. За создание учебного плана был назначен отвечать недавно вышедший в отставку генерал, а Военно-морской стратегический колледж США предоставит рекомендации и методологию разработки. Это будет курс, в центре 
которого лежат не только вопросы высшей стратегии и национальной безопасности, но и проблемы совместных операций. Профессорско-преподавательский состав ВКВС работает над вопросом получения аккредитации для магистерской степени по национальной безопасности для выпускников этого курса.

\section{Вызовы впереди}

Хотя нельзя не признать успехи, достигнутые программой НАТО ПСОСО в Азербайджане за такой короткий срок (три года), все еще остаются камни преткновения. Во-первых, основной проблемой в разработке новых учебных планов остается то, что темы и семинары, разработанные для курса оперативно-тактического уровня, теперь надо или перенести, или расширить для курса стратегического уровня. Далее, для каждого нового курса, разработанного ВКВС, необходимо нанимать и готовить новый преподавательский состав. Со своей стороны, Военноморской стратегический колледж США принял на себя обязательство использовать следующее мероприятие по программе «дублирование преподавателей» для оказания помощи разработке курса для высших офицеров и обеспечить достаточное время пребывания азербайджанским разработчикам курса в качестве дублеров преподавателей из департамента совместных военных операций. После создания этого курса программа НАТО ПСОСО и ВКВС должны будут проверить сверху донизу все курсы обучения, чтобы удостовериться, что между ними нет пустот или ненужного дублирования. Идея в том, чтобы обеспечить устойчивое и логическое развитие программы совместного профессионального военного образования для лейтенантов, старших офицеров и генералов.

Во-вторых, реализации проектов программы НАТО ПСОСО на всех уровнях (обучение сержантов, специализация офицеров и докторские программы) будет содействовать хорошее знание английского языка в азербайджанских вооруженных силах. НАТО продолжает предоставлять поддержку языковой подготовке через БМЯК, а некоторые государства предоставляют свою помощь на двухсторонней основе, и Азербайджану рекомендуется в большей степени использовать эти возможности. Целостное улучшение знания английского языка было бы особенно полезно при создании более профессионального корпуса сержантов. Принцип «Тренировать тренеров» имеет большое приложение в курсах для сержантов, и особое внимание должно быть обращено на пропасть между рядовым и офицерским составом вооруженных сил Азербайджана.

В-третьих, зацикленность Азербайджана на нагорно-карабахском конфликте и его враждебность к Армении затрудняет сосредоточение внимания на стратегических вопросах вне этой проблемы. Как только инструктор из НАТО отвлечется на мгновение, каждое обсуждение в классе неизбежно возвращается к Нагорному Карабаху. Необходимо расширение стратегического кругозора вне этого назойливого конфликта, если мы хотим осуществление настоящих реформ в азербайджанском образовании в сфере обороны. 


\section{Перспективы на будущее}

В Азербайджане наличествуют все признаки жизненности и благополучия. Недавний конкурс Евровидения, состоявшийся в Азербайджане, стал источником гордости для граждан страны и дал возможность европейским туристам воочию убедиться в достигнутом прогрессе. Хотя Баку делает все возможное, чтобы не допустить ухудшения отношений ни с кем из своих соседей, все чаще говорят, что Азербайджан становится бастионом Запада на Кавказе - короче, «всем тем, чем Иран не является». ${ }^{1}$ Хотя это путь, трудности которого нельзя переоценить, расширяющиеся связи азербайджанских военно-учебных заведений с западной системой военного образования и с западным военным мышлением неизбежно приближает этот существенный компонент его общества к НАТО. Успех азербайджанской программы ПСОСО, хотя еще краткосрочный и все еще развивающийся, дает основания и возможности для серьезного вклада в развитие этих связей. В результате, Азербайджан медленно и незаметно начинает поворачивать свой взор на Запад.

Joby Warrick, “Tiny Azerbaijan Unleashes Pop-Power Against Iran’s Mullahs," Washington Post (14 October 2012). 
OCEHb 2012

\section{Bibliography}

Warrick, Joby. "Tiny Azerbaijan Unleashes Pop-Power Against Iran's Mullahs." Washington Post (2012). 